\title{
The Religious Hermeneutics of Gerhard Oberhammer and the Investigation of the Philosophical Traditions of India
}

\author{
Halina Marlewicz \\ Institute of Oriental Studies \\ Jagiellonian University \\ Krakow, Poland \\ E-mail: halina.marlewicz@uj.edu.pl
}

\begin{abstract}
Gerhard Oberhammer (1929-), the Austrian Indologist and philosopher of religion, developed the transcendental hermeneutics of religion as an in-depth analysis of the phenomenon of religiosity. One of its themes is a religious experience in a comparative perspective. In order to conduct the phenomenological-existential analysis of what religious experience is and how it happens, Oberhammer develops a network of notions, which jointly create a coherent system of religious hermeneutics. The notion of the "encounter" (Begegnung), interpreted as a universally essential dimension of religious experience, explains the event of experiencing transcendence by the subject and is pivotal to the system. The introductory part of the article is meant to sketch the intellectual biography of Gerhard Oberhammer, with the aim to provide concise information about the profile of the thinker. In the second part the outline of the system of the transcendental hermeneutics of religion will be introduced, in a wider context of possible affinities to other thinkers. Lastly, the applicability of the hermeneutics to philosophical traditions of India will be considered.
\end{abstract}

Keywords-hermeneutics; religiosity; religious experience; "encounter"; "mythization"

\section{INTRODUCTION}

In 1988, in an interview for the magazine Das Fenster, Oberhammer explained his approach to religion in the following manner:

According to me, hermeneutics is an attempt to interpret the phenomenon of religion, not, however, in the sense of the theological understanding of what religion is, but in the sense of religion as a human phenomenon, unrestricted by dogmatic positions. Why does man have religion, in what does the essence of religion lie?

Further on he added:

In my view, hermeneutics is a scholarly investigation of the understanding of not only the text but also the phenomenon [1].

In the interview, Oberhammer refers to his system of the transcendental hermeneutics of religion as related to the question of how to approach methodologically human religiosity, given the multiplicity of doctrines and beliefs. This question became vital for him already in 1957. In the same interview, when describing his passage to India on a Dutch freighter in this very year, and his first encounter with India - both as a scholar and a practicing Catholic Oberhammer spoke of experiencing "foreign religiosity" as crucial for his academic and intellectual formation. It is then that he asked himself the following questions:

How should one $[\ldots]$ find access to this foreign religion without modifying one's own principles, one's own worldview, one's own religion? The question was more and more decisive for my work, not only in the field of research but also existentially, for the development of my entire spirituality. [...] And what happens, when a man not only has religion but lives it? [2]

In this intimate confession, there is expressed a sincere concern of a philosopher and a practicing believer, who is confronted with, and exposed to, the foreign forms of religion, but who also attempts to critically and rationally examine the problem without relativizing the validity of his own faith. Therefore, it seems that the primary motivation for Oberhammer's hermeneutical reflection on religion was rooted in the existential context of being exposed to a foreign form of religiosity and trying to approach it in an unbiased manner. In the present times, with growing tension over religious issues, it seems important to emphasize this aspect of the otherwise highly theoretical approach.

The method, defined by its author as a transcendental hermeneutic of religion, was developed systematically over the years and always showed a sympathetic and sensitive interpretation of "foreign forms" of faith. It also became conducive to the analysis and interpretation of religiosity in which man and the process of living religion, that is: of existentially experiencing it, constitute the core of enquiry and the center of interpretation. Questions posed in the interview, simple as they seem - Why does man have religion, in what does the essence of religion lie? What happens, when a man not only has religion but also lives it? - have always remained in the background of Oberhammer's 
theoretical reflection, thereby situating his transcendental hermeneutics of religion in the sphere of existentialontological approach.

\section{TRANSCENDENTAL HERMENEUTICS}

The term "transcendental", which determines Oberhammer's hermeneutics could possibly be taken as an indication at a certain intellectual affinity to the old tradition of German "transcendental idealism", with its focus on the relation of thought and existence. Indeed, the general transcendental-idealistic background of the transcendental hermeneutics shows some traces of German idealism.

This affinity to idealism, however, is better substantiated by the idea of human transcendentality, the key assumption of the system, which "presupposes the openness of «selfpresence» of the self to another subject" [3]. That openness to the other is the basis of the transcendental structure of consciousness. Such presuppositions can be found in the thought of the influential Catholic theologian and thinker Karl Rahner (1904-1984). In the final remarks on the structure of the cognizing subject, cognitive act, and cognition as such he concludes:

Subjective, athematic and present in every act of cognition, necessary and non-abrogable co-consciousness of the knowing subject and its openness to the unlimited scope of every possible reality is called the transcendental experience. [...] This experience is called transcendental, because it belongs to the necessary and non-abrogable structure of the knowing subject, and because it consists of precisely going beyond a certain group of possible objects, going beyond a category. [4]

As the subject's openness is a necessary condition of every cognitive act, the idea of openness should be taken as the pre-condition on knowing. It therefore seems that Rahner primarily relates the idea of the subject's openness to the epistemic questions. Although Oberhammer may owe the idea of the subject's openness to Rahner, he conceptualizes it differently. The ultimate openness of the subject's "selfpresence" (Beisichsein), or - in other words - "selfawareness", Oberhammer understands not as related to the knowing of the subject but as its ontic dimension or conditioning, which is both prior (if not a priori), and primary to the transcendentality of the subject's consciousness. Therefore, the subject's openness in Oberhammer's thought is not the condition of knowing but of being.

It should be, however, added, that both thinkers share the idea that the subject is "fundamentally and of its own nature pure openness to absolutely everything, and above all to being." [5]

Oberhammer's overall theoretical discourse also shows a certain affinity to the existential and phenomenological approach of Martin Heidegger ${ }^{1}$, which is substantiated

This affinity has been first recognized by Desiree Berendsen, cf. her unpublished M.A thesis written in Dutch Theologischer schnaps. Het antropologisch fundament van religie an haar inhoud bij G. Oberhammer, pp. 15-22. mostly in the thinker's philosophical vocabulary. ${ }^{2}$ The conceptual meta-structure used for the theoretical description of two original and fundamental notions of the "Mythization" (Mythisierung) and the "Encounter" (Begegnung), seems to be founded on Heideggerian phenomenology, in which the ontic structure of "being-inthe-world" (Dasein) is presupposed as an a priori point of departure and condition of every act of cognition of the subject. However, Oberhammer, as shown above, presupposes the transcendental horizon of cognition of the one "being-in-the-world", and in that regard, he clearly differs from Heidegger.

Two key-notions of the transcendental hermeneutics: "Mythization" (Mythisierung) and "Encounter" (Begegnung) - by their belonging respectively to the sphere of linguistic representation of an object of cognition, and to the sphere of existence - jointly create the thought-existence relation and refer the system to the co-occurrence of language and reality. Mythization, which is supposed to enable an encounter with transcendence, it is a process in which and by which transcendence gets its "face" and becomes appropriated and approachable in the religious tradition. Emphasis on thoughtexistence relation brings to the fore man's inherent ability of noetic, intuitive-intellectual cognition, which seems to be required in investigating the transcendent reality and its experience in and via the language ${ }^{3}$.

In the dialectic situation of the encounter explained as the dynamic event of the relationality, the act of transcendental "reaching-out" of the subject towards the absolute Other (i.e. transcendence), in which it relates to the absolute Other, the subject establishes its self-presence (Beisichsein) in its fullness. It is during the inexplicable event of the dynamic,

Befindlichkeit - state of mind, attunement, Dasein - existence, "the being-here", Mitsein - co-being, the frequent use of prefix vor- (pre) to indicate the event or condition prior to something, to mention a few, frequently used terms in the transcendental hermeneutics, which are Heideggerian in their 'atmosphere'

One has to note that Oberhammer started to work on the keyideas of his system of transcendental hermeneutics before 1987. The question of how to approach different forms of faith was articulated first in the text of 1974: "Offenbarung, geistige Realität des Menschen. Entwurf einer Einleitung". General reflection on the experience of transcendence is to be found in the article: "Transzendenzerfahrung, Vollzughorizont des Heils. Reflexion eines Ansatzes" of 1978. The structure of religious tradition and revelation as phenomena in Hinduism, discussed also in a more general, theological context, were the focus of the text

"Überlieferungsstruktur und Offenbarung. Aufriss einer Reflexion des Phänomens im Hinduismus mit theologischen Anmerkungen“", published in 1980. There, the corpus of revelation is seen as the bearer and mediator of the revelation of transcendence and the framework for experiencing transcendence by the subject. „Epiphanie des Heils. Fragmentarische Bemerkungen zur Struktur des Phänomens“, written in 1982, introduces the reader into the basic presuppositions of the system of transcendental hermeneutics of religion. It speaks, among others, about the particular understanding of the phenomenon of religion, the transcendental basis of human consciousness and its dialogical character; the phenomenon of selfcommunication of transcendence. On the chronology of Oberhammer's works on the hermeneutic of religion, see also Francis X. D'Sa, “The Remembering of Text and Tradition. Some Reflections on Gerhard Oberhammer's Hermeneutics of Encounter". In: Hermeneutics of Encounter. Essays in Honour of Gerhard Oberhammer on the occasion of His $65^{\text {th }}$ birthday. Publications of the De Nobili Research Library. Vienna 1994, p. xxiv, n. 26. 
non-reified unity of the two horizons (i.e. the horizon of the transcendental subject and of the transcendence as selfcommunicating openness) that the subject - by remaining in the presence of this self-communicating openness constitutes itself anew. It is also the self-communicating openness of the Other ${ }^{4}$ that becomes the condition of the subject's transcendental structure.

\section{UNIVERSALISTIC AND PERSONALISTIC INVESTIGATION OF RELIGION}

Oberhammer's system has an overall methodological aim of providing tools for phenomenological investigation of religiosity as a universal, human phenomenon. His analyses and interpretations aim at distilling the essential features of religiosity in order to abstract it from the context of the theological presuppositions of the given religious tradition. The aim can be seen as essentialization or universalization, since it focuses exclusively on the subject's experience of transcendence (the "beyond-of-being", Jenseits des Seienden), in order to extract only the essence of religiosity present at the core of the given religious system.

Secondly, the religious experience is interpreted as an "encounter" (Begegnung), which "happens" in the very interiority of the experiencing human subject, and which gives the sense of an ultimate fulfilment of life. For Oberhammer, religion is primarily the factor inducing the event of encountering transcendence, in which event the innermost, spiritual structure of man becomes completely and irreversibly re-shaped in the absolute, radical claim of such an encounter. The thinker considers it the most intense experience in the spiritual life of man, which grants the immediateness to the reality of the "beyond-of-being-being"5. The question as to how man becomes a homo religious and the attempts to answer it are introduced from the perspective of an individual, who is seen as the locus of the revelation ${ }^{6}$. Such understanding of an "encounter" gives it its personalistic tinge. The thinker also interprets religiosity in relation to the historicity and particularity of the tradition, as it endows the experience of transcendence with its own, specific character.

Such understanding of religion and religiosity, the phenomenological analysis of their function, and the focus on their existential dimension co-create the transcendental hermeneutics of religion of Oberhammer.

\footnotetext{
4 The self-communicating openness of the transcendence is that, which establishes the complete and unreserved openness of the subject in his innermost self, in its reaching out to it.

Cf. Oberhammer, G. (1987). Versuch einer transzendentalen Hermeneutik Religiöser Traditionen (Occasional Papers 3). (G. Oberhammer, Ed.) Wien: Publications of the De Nobili Research Library; Idem, (1989). Begegnung als Kategorie der Religionshermeneutik (Vol. 4 'Occasional Papers'). (G. Oberhammer, Ed.) Wien: Publications of the De Nobili Research Library.

6 Cf. Oberhammer, G. (1984). Der Mensch als Ort der Offenbarung. In A. Bsteh (Ed.), Sein als Offenbarung in Christentum und Hinduismus (Beiträge zur Religionstheologie 4). Mödling: Verlag St. Gabriel, pp. 17-36.
}

\section{CONCLUSION}

The methodological question which Oberhammer posed at the beginning of his investigations into the forms of "foreign religiosity" that is: how to approach the phenomenon of human religiosity universally, without recurring to any specific theology, led the philosopher to develop the intricate system of the transcendental hermeneutics of religion. The system is grounded on a tightly interlaced net of concepts, which, in spite of its elegance and philosophical sophistication, makes it quite hermetic.

The concepts such as the "reaching-out" (Ausgriffe), the „encounter" (Begegnung), the "mythization" (Mythisierung), "Self-presence" (Beisichsein), the" beyond-of-being" (Jenseits des Seienden), the "one towards whom one reaches out" (Woraufhin) are all meant to be theologically neutral and go beyond particular presupposition of a given theology. They are introduced in order to avoid the projection of a specific onto-theology onto the transcendental hermeneutical approach. Yet it is precisely this conceptual neutrality, which can create a problem of the hermeneutical circle. One is confronted with the linguistic expressions, which are parts of the whole meaningful system, and if the whole system is not internalized, the implications of its particular conceptualizations can be difficult to follow.

Oberhammer's transcendental metaphysics of religiosity structured within the frames of his hermeneutics creates, therefore, some problems with regard to its applicability, also with regard to the investigation of the philosophical traditions of India. Yet, despite some reservations, it seems to remain one of the least biased approaches to investigate 'foreign religiosity'. In its effort to remain neutral and an unbiased in approach, it emphasizes the core of theistic religions, not the differences. Its anthropo-philosophical perspective is attractive for investigating chosen philosophical traditions of India, in which emancipation, and the way which leads to it, are the main concern.

The Vedāntic interpretations of revelatory texts, which are, in fact, "religious hermeneutics", can, with some reservations, become subject to investigation by means of Oberhammer's hermeneutics. Indian religious-philosophical systems, which discuss the ways and means to realize the ultimate, soteriological aim of human life, require a particular methodological approach, which the hermeneutics of Oberhammer is able to provide [6]. It offers a possibility of a scientific investigation of the phenomena of which the text speaks and is able to result in a "comprehensive understanding" of the aim of human life in spiritual emancipation, in the manner in which it is attested in the Indian texts related to salvific systems.

Some of the traditions of Indian thought cannot be explored by means of Oberhammer's hermeneutical tools. An evident example would be the formalist and analytical approaches, such as purely ontological questions of the Vaiśeșika categories, or, obviously, the systems which are atheistic or non-theistic. This Oberhammer admits in the introductory remarks to his work Versuch einer Transcendentalen Hermeneutik Religiöser Traditionen. 


\section{REFERENCES}

[1] Pflaundler, W. (1988). Das Tiroler Porträt. Der Indologe Gerhard Oberhammer. Tiroler Kultur Zeitschrift Das Fenster, 22(44), p. 4358, col. 1 .

[2] Ibid., p. 4355, col. 1.

[3] Oberhammer, G. (1992). Hermeneutics of Religious Experience. In G. Oberhammer, \& J. D. al. (Ed.), On Sharing Religious Experience. Possibilities of Interfaith Mutuality (Currents of Encounter 4). Amsterdam, p. 14.

[4] Rahner, K. (1997). Grundkurs des Glaubens. Einfürung in den Begriff des Christentums. Freiburg et al.: Herder, p. 31.

[5] Ibid.

[6] Marlewicz, H. (2004). Towards a methodological approach to the hermeneutics of early Vedānta. (Renata Czekalska, \& H. Marlewicz, Eds.) Cracow Indological Studies, 4/5, pp. 355-356.

[7] Berendsen, D. (n.d.). Theologischer schnaps. Het antropologisch fundament van religie an haar inhoud bij G. Oberhammer (an unpublished M.A. Thesis).

[8] D'Sa, F. X. (1994). The Re-membering of Text and Tradition. Some Reflections on Gerhard Oberhammer's Hermeneutics of Encounter. In Hermeneutics of Encounter. Essays in Honour of Gerhard Oberhammer on the occasion of His 65th birthday (pp. p. XXIV, n. 26). Vienna: Publications of the De Nobili Research Library.

[9] Marlewicz, H. (2004). Towards a methodological approach to the hermeneutics of early Vedānta. (Renata Czekalska, \& H. Marlewicz, Eds.) Cracow Indological Studies, 4/5, pp. 349-358.

[10] Oberhammer, G. (1974). Offenbarung, geistige Realität des Menschen. Entwurf einer Einleitung. In G. Oberhammer, Offenbarung, geistige Realität des Menschen. Arbeitsdokumentation eines Symposiums zum Offenbarungsbegriff in Indien. Wien: Publications of the De Nobili Research Library (Vol. II), pp. 13-27)

[11] Oberhammer, G. (1978). Transzendenzerfahrung, Vollzughorizont des Heils. Reflexion eines Ansatzes. In G. Oberhammer (Ed.), Transzendenzerfahrung, Vollzughorizont des Heils. Das Problem in indischer und christlicher Tradition. Wien: Publications of the De Nobili Research Library (Vol. V), pp. 7-12.

[12] Oberhammer, G. (1980). Überlieferungsstruktur und Offenbarung. Aufriss einer Reflexion des Phänomens im Hinduismus. In G. Oberhammer, \& H. Waldenfels, Überlieferungsstruktur und Offenbarung. Aufriss einer Reflexion des Phänomens im Hinduismus mit theologischen Anmerkungen (Vol. 1 'Occasional Papers'), Wien: Publications of the De Nobili Research Library, pp. 11-36.

[13] Oberhammer, G. (1982). Epiphanie des Heils. Fragmentarische Bemerkungen zur Struktur des Phänomens. In G. Oberhammer (Ed.), Epiphanie des Heils. Zur Heilsgegenwart in indischer und christlicher Religion. Arbeitsdokumentation eines Symposiums. Wien: Publications of the De Nobili Research Library (Vol. IX), pp. 217226.

[14] Oberhammer, G. (1984). Der Mensch als Ort der Offenbarung. In A. Bsteh (Ed.), Sein als Offenbarung in Christentum und Hinduismus (Vol. 4 'Beiträge zur Religionstheologie'). Mödling: Verlag St. Gabriel, pp. 17-36.

[15] Oberhammer, G. (1987). Versuch einer transzendentalen Hermeneutik Religiöser Traditionen (Vol. 3 'Occasional Papers'). (G. Oberhammer, Ed.) Wien: Publications of the De Nobili Research Library.

[16] Oberhammer, G. (1989). Begegnung als Kategorie der Religionshermeneutik (Vol. 4 'Occasional Papers'). (G. Oberhammer, Ed.) Wien: Publications of the De Nobili Research Library.

[17] Oberhammer, G. (1992). Hermeneutics of Religious Experience. In G. Oberhammer, \& J. D. al. (Ed.), On Sharing Religious Experience. Possibilities of Interfaith Mutuality (Vol. 4 'Currents of Encounter'). Amsterdam, pp. 13-24.

[18] Oberhammer, G. (2003). Transzendenzerfahrung als absolute Begegnung (Vol. 6 'Occasional Papers'). (G. Oberhammer, \& U. Podzeit, Eds.) Wien: Publications of the De Nobili Research Library.
[19] Pflaundler, W. (1988). Das Tiroler Porträt. Der Indologe Gerhard Oberhammer. Tiroler Kultur Zeitschrift Das Fenster, 22(44), pp. 4352-4365.

[20] Rahner, K. (1997). Grundkurs des Glaubens. Einfürung in den Begriff des Christentums. Freiburg et al.: Herder. 